\title{
Editorial \\ Exigència en/sobre la formació de mestres
}

Hi ha gairebé un consens entre els economistes a l'hora de constatar que l'educació és un dels factors fonamentals per aconseguir prosperitat $\mathrm{i}$ creixement econòmic en els països. La inversió en allò que s’anomena "capital humà" és essencial per augmentar la productivitat i millorar la capacitat d'innovació. L'interès que va tenir en el seu moment l'OCDE per promoure les proves PISA s'ha d'entendre també com una manera de mesurar el "capital humà" dels països, un dels factors essencials per decidir les inversions empresarials. En conseqüència, alguns països han optat per considerar la despesa en el sistema educatiu (i, és clar, el control de la seva eficiència) com un element remarcable en les seves prioritats pressupostàries.

Tanmateix, aquest discurs economicista tan habitual té uns perills evidents: que l'escola sigui percebuda prioritàriament com una formadora de mà d'obra (barata o cara, i ens temem que al nostre país predominarà la primera opció), i que els resultats siguin mesurats sols en funció de si ha aconseguit que els futurs treballadors tinguin capacitat d'adaptar-se al mercat laboral. I nosaltres, professionals de l'ensenyament, tenim la convicció que hi ha altres elements molt més importants com la dignitat humana, la capacitat per comprendre el món en què es viu o allò que la Declaració d'independència dels Estats Units va expressar amb tanta claredat: que el dret a la vida, la llibertat i la recerca de la felicitat són uns dels drets inalienables de qualsevol persona.

Agafem la perspectiva que agafem, sabem que el progrés (tant en la seva concepció més limi- tada i economicista com en la concepció més social) passa per l'educació i que els resultats no s'acostumen a percebre d'una manera nítida fins al cap d'una generació. I al nostre país, la realitat de les decisions governamentals no sembla del tot coherent amb aquesta evidència. Des del començament de la crisi al nostre país, l'any 2008, quin haurà estat l'impacte de l'empitjorament de les condicions de treball a les nostres escoles? Quantes energies i temps s'hauran perdut amb una llei educativa - la LOMCE - que presumiblement tindrà una vida ben curta?

I per què ha aparegut aquest interès per controlar la qualitat de la feina a les escoles, amb proves externes, i en canvi ningú no gosa posar proves externes als estudiants que surten de les facultats d'educació? Qui controla la veritable formació que reben els matriculats als màsters de formació de professorat d’educació secundària? Alguns anuncis i decisions de la Conselleria d'Ensenyament, com l'augment de l'exigència acadèmica per poder cursar els graus d'Educació Infantil i Primària, semblen mostrar que té consciència d'aquests problemes en un element nuclear del nostre sistema educatiu. Però de vegades s'ha donat la impressió que eren idees massa improvisades, que existia timidesa a l'hora de plantejar-les, i no podem descartar que acabin provocant reaccions defensives des de les universitats. Caldrà que hi hagi uns objectius ben establerts i ser conscients que tots els implicats ens devem a la societat. 